\title{
Performance of a Multicrystalline Photovoltaic Module in Critical Climatic Conditions of Western Rajasthan, India
}

\author{
Shalini Garg \\ Government Polytechnic \\ College, Jodhpur, India
}

\author{
Arun J. B. \\ Directorate of Technical \\ Education, Jodhpur, India
}

\author{
D. C. Surana \\ MBM Engineering College, \\ Jodhpur, India
}

\begin{abstract}
The energy yield of a Photovoltaic (PV) power plant depends upon the dc power output of the PV module. The irradiance and temperature are the two most important parameters affecting the dc power output. This paper analyses the dc power output of a multicrystalline PV module in the realistic environmental condition with respect to solar irradiance, ambient temperature and cell temperature. The real time data is collected from a $5 \mathrm{MW}$ grid connected solar PV plant located in Jaisalmer, a district in Western Rajasthan. The paper brings forward a crucial and valuable fact that the modules work more efficiently at high temperature and high solar irradiance. For a multicrystalline PV module with maximum dc power output $\left(\mathrm{P}_{\max }\right)$ at $\mathrm{STC}$ condition equal to $118.687 \mathrm{KW}$, analyzed over a period of one year it is found that maximum $\mathrm{dc}$ power output $\left(\mathrm{P}_{\mathrm{dc}}\right)$ at $22^{\circ} \mathrm{C}$ ambient temperature and 40 cell temperature is only $72 \mathrm{KW}$ while maximum $\mathrm{P}_{\mathrm{dc}}$ at cell temperature around $50-55^{\circ} \mathrm{C}$ and ambient temperature around $35-38^{\circ} \mathrm{C}$ is $90-92 \mathrm{KW}$. Slight negative temperature coefficient for $\mathrm{P}_{\mathrm{dc}}$ with respect to temperature is observed if ambient temperature and cell temperature is greater than $35^{\circ} \mathrm{C}$ and $50^{\circ} \mathrm{C}$ respectively. However power output increases in direct proportion to irradiance outweighing the change in temperature. Higher the irradiance, higher is the dc power output, higher is the efficiency and correspondingly higher is the energy yield of the PV module. The multicrystalline PV module works efficiently and gives high yield in the extremely high temperature of Western Rajasthan. Rajasthan which receives world second largest radiation has the capability to meet the energy demands of India and the world as well if solar energy is harnessed in appropriate way.
\end{abstract}

\section{General Terms}

Solar photovoltaic, Power output, Performance of PV module

\section{Keywords}

Performance of PV module, Ambient temperature, Cell temperature, DC power output, Multicrystalline Photovoltaic module, Western Rajasthan, Critical climatic condition.

\section{INTRODUCTION}

Sun the driving power to photovoltaic is an inexhaustible source of energy. It provides about 10,000 times more energy than we consume. The solar photonic cells convert the light spectrum directly to electricity. A single cell produces about $0.5 \mathrm{~V}$. Cells are wired in series to form either $12 \mathrm{~V}$ or $24 \mathrm{~V}$ module. In turn modules are connected in series and parallel to increase voltage and current respectively to obtain desired power output. With reference to cell temperature $25^{\circ} \mathrm{C}$, the short circuit current $\left(\mathrm{I}_{\mathrm{sc}}\right)$ increases in direct proportion to irradiance while open circuit voltage $\left(\mathrm{V}_{\mathrm{oc}}\right)$ undergoes modest positive change. At the same time, with increase in cell temperature above $25^{\circ} \mathrm{C}, \mathrm{V}_{\mathrm{oc}}$ decreases substantially while the short circuit current increases only slightly [1].The result is that power output decreases with increase in cell temperature above $25^{\circ} \mathrm{C}$. However in one of the paper entitled "High Temperature Effect on Multicrystalline Photovoltaic Module in Western Rajasthan, India”, it has been shown that dc output voltage does not decrease with increase in cell temperature above $25^{\circ} \mathrm{C}$ instead stable and high dc output is obtained only when cell temperature is greater than $50^{\circ} \mathrm{C}$ [2]. The results of the above paper are further verified by the work done in this paper. This paper correlates dc power output of a multicrystalline PV module with Global Horizontal Irradiance (GHI), ambient temperature and cell temperature for real time data. The real time data is collected from a 5MW solar PV power plant located in Ramgarh, district Jaisalmer, one of the hottest cities of Western Rajasthan. The results of analyses clearly show that dc power obtained at cell temperature $50^{\circ} \mathrm{C}$ is far greater than obtained at cell temperature $25^{\circ} \mathrm{C}$. $\mathrm{P}_{\mathrm{dc}}$ as high as $86.71 \mathrm{KW}$ is obtained at $62^{\circ} \mathrm{C}$ cell temperature while $\mathrm{P}_{\mathrm{dc}}$ obtained at $25^{\circ} \mathrm{C}$ cell temperature is insignificant. The result is in accordance to paper [2] where it was concluded that $\mathrm{dc}$ output voltage shows negative temperature coefficient for cell temperature greater than $52^{\circ} \mathrm{C}$ and not $25^{\circ} \mathrm{C}$. The existing literature and even manufacturers do specify negative temperature coefficient for maximum power output $\left(\mathrm{P}_{\max }\right)$ with reference to $25^{\circ} \mathrm{C}$ cell temperature. The value of temperature coefficient for $\mathrm{P}_{\max }$ for the module that has been used in the plant is $-0.447 \% /{ }^{\circ} \mathrm{K}$ as shown in table number 2 . However the result show slight negative temperature coefficient if ambient temperature and cell temperature are greater than $35^{\circ} \mathrm{C}$ and $50^{\circ} \mathrm{C}$ respectively. Ambient temperature, cell temperature and irradiance vary due to various environmental factor like wind speed, wind direction, humidity, cloud, dust storm and dust clouds a peculiar feature of Western Rajasthan but overall dc power output increases with increase in irradiance showing that irradiance is the dominating factor in determining the dc power. High irradiance at high temperature for long duration and for almost eleven months can lead to highly efficient solar PV plant in Western Rajasthan. Thus Rajasthan receiving second largest amount of radiation in the world as per studies conducted by U.S Department of Energy [3] has enormous potential in the field of photovoltaic. It receives about 6-7 $\mathrm{KWh} / \mathrm{m}^{2}$ of solar insolation with about 325 sunny days [4]. It has the capability to meet the energy demands of the world provided solar energy is harnessed in a way that maximum irradiance is captured. 


\section{METHODOLOGY}

2.1 The data set used in analysis is from one of the $5 \mathrm{MW}$ grid connected PV power plant located at Ramgarh, in district Jaisalmer, Rajasthan, India.

2.2 The characteristic of the PV module are specified at STC condition shown in Table 1. The data and result correspond to multicrystalline module with specifications as shown in Table 2.

2.3 The global horizontal irradiance is measured by Pyranometer at 15 minutes interval and stored by the SCADA (Supervisory Control and Data Acquisition) system.

2.4 The analysis is based on variation of dc power output of a multicrystalline PV module specifically PV array with maximum power output equal to $118.687 \mathrm{KW}$.

2.5 The panel temperature corresponds to cell temperature in the graph shown in the paper

2.6 The average DC power of five arrays over a period of one year May 2014 to April 2015 has been analyzed.

2.7 The effect of various other environmental parameter like wind speed, wind direction, humidity, cloud, dust particle, dust storms and dust clouds etc. have not been considered in the present analyses.

2.8 The graph leading to vital conclusions have been shown in the paper.

2.9 AMB, PANEL, PDC corresponds to ambient temperature, panel temperature and dc power output respectively in the graphs. The short forms are followed by the related date for example PDC 11-3-15 means dc power output for 11 march 2015 .

Table 1. STC condition

\begin{tabular}{|c|l|l|}
\hline S. No & Parameters & Value \\
\hline 1 & Irradiance & $1000 \mathrm{~W} / \mathrm{m}^{2}$ \\
\hline 2 & Module Temperature & $25^{\circ} \mathrm{C}$ \\
\hline 3 & Air Mass & 1.5 \\
\hline 4 & $\begin{array}{l}\text { NOCT (Nominal Operating } \\
\text { Cell Temperature) }\end{array}$ & $47^{\circ} \mathrm{C}$ \\
\hline 5 & Operating Temperature & $-40^{\circ} \mathrm{C}$ to $+85^{\circ} \mathrm{C}$ \\
\hline
\end{tabular}

Table 2. MBSL Elite PV Module Characteristic

\begin{tabular}{|c|l|l|}
\hline S. No. & Electrical Characteristics & Values \\
\hline 1. & Maximum power $\mathrm{P}_{\operatorname{mpp}} / \mathrm{P}_{\max }$ & $247.39 \mathrm{~W}$ \\
\hline 2. & Voltage at $\mathrm{P}_{\max }, \mathrm{V}_{\mathrm{mpp}}$ & $30.64 \mathrm{~V}$ \\
\hline 3. & Current at $\mathrm{P}_{\max }, \mathrm{I}_{\mathrm{mpp}}$ & $8.07 \mathrm{~A}$ \\
\hline 4. & Open circuit voltage $\mathrm{V}_{\mathrm{oc}}$ & $37.67 \mathrm{~V}$ \\
\hline 5. & Short circuit current $\mathrm{I}_{\mathrm{sc}}$ & $8.26 \mathrm{~A}$ \\
\hline 6. & Temperature coefficient of $\mathrm{P}_{\max }$ & $-0.447 \% /{ }^{\circ} \mathrm{K}$ \\
\hline
\end{tabular}

\begin{tabular}{|c|l|l|}
\hline 7. & Temperature coefficient of $\mathrm{V}_{\mathrm{oc}}$ & $-0.353 \% /{ }^{\circ} \mathrm{K}$ \\
\hline 8. & Temperature coefficient of $\mathrm{I}_{\mathrm{sc}}$ & $0.104 \% /{ }^{\circ} \mathrm{K}$ \\
\hline 9. & Power Tolerance & $-0 /+5 \mathrm{~W}$ \\
\hline 10. & Fuse rating & $15 \mathrm{~A}$ \\
\hline 11. & Maximum System Voltage & $1000 \mathrm{~V}$ \\
\hline 12. & Maximum array voltage & $\begin{array}{l}735.36 \mathrm{~V} \\
(24 * 30.64)\end{array}$ \\
\hline 13. & Maximum array current & $\begin{array}{l}161.4 \mathrm{~A} \\
(8.07 * 20)\end{array}$ \\
\hline 14. & Maximum array power & $\begin{array}{l}118.687 \mathrm{KW} \\
(735.36 * 161.4)\end{array}$ \\
\hline
\end{tabular}

\section{EXPERIMENTAL DATA ANALYSIS}

The effect of GHI on dc power output of the multicrystalline PV array has been analyzed for very high temperature considering four specific dates $15^{\text {th }}$ April 2015, 26 ${ }^{\text {th }}$ May $2014,5^{\text {th }}$ June 2014 and $6^{\text {th }}$ July 2014 (Figure 1). The $\mathrm{dc}$ power output $\left(\mathrm{P}_{\mathrm{dc}}\right)$ increases with increase in GHI. It can be seen that constantly increasing and high $\mathrm{P}_{\mathrm{dc}}$ is obtained for GHI greater than $700 \mathrm{~W} / \mathrm{m}^{2}$. The corresponding cell temperature is around $42-52^{\circ} \mathrm{C}$ for $\mathrm{GHI}$ greater than $700 \mathrm{~W} \mathrm{~m}{ }^{2}$.

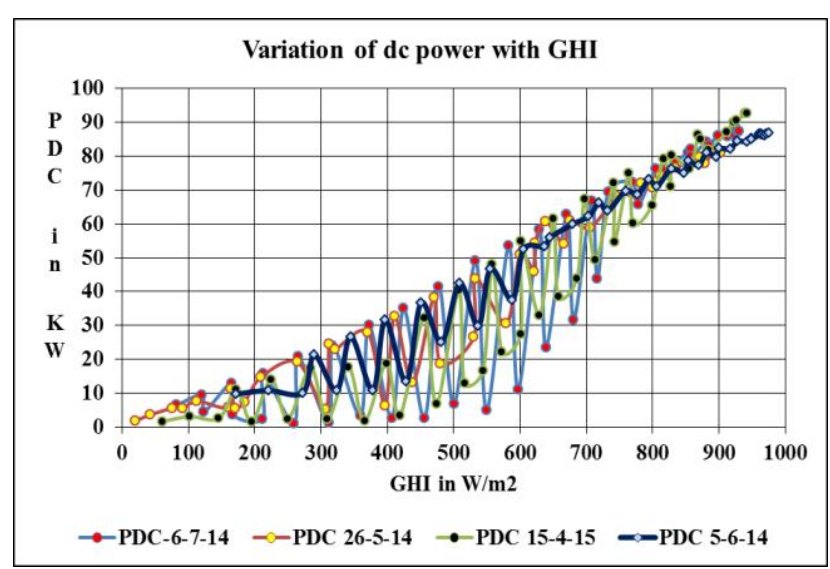

Fig 1: Variation of $P_{d c}$ with GHI in summer (April-July).

The detailed analyses of $\mathrm{P}_{\mathrm{dc}}$ with GHI are shown in figure 2 and figure 3 .

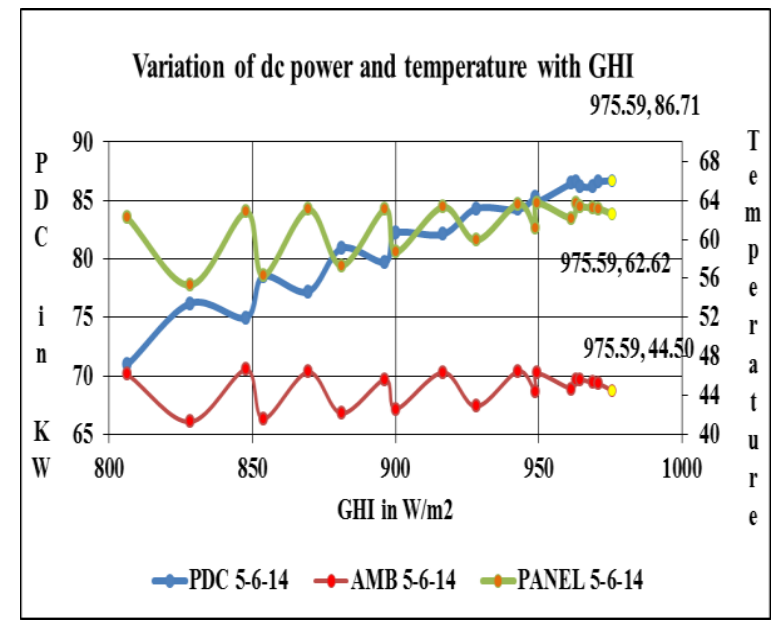

Fig 2: Variation of $P_{d c}$ with GHI greater than $800 W / m^{2}$ for $5^{\text {th }}$ June 2014. 
Figure 2 shows variation of $\mathrm{P}_{\mathrm{dc}}$ with $\mathrm{GHI}$ greater than $800 \mathrm{~W} / \mathrm{m}^{2}$, ambient temperature varying in the range of 40 $45^{\circ} \mathrm{C}$ and cell temperature varying in the range of $56-64^{\circ} \mathrm{C}$. It can be seen that as ambient temperature and cell temperature increase $P_{d c}$ reduces and vice versa but still $P_{d c}$ increases from $70 \mathrm{KW}$ to $86.71 \mathrm{KW}$ as $\mathrm{GHI}$ increases from 800 to 975.59 $\mathrm{W} / \mathrm{m}^{2} . \mathrm{P}_{\mathrm{dc}}$ equal to $86.71 \mathrm{KW}$ is obtained at cell temperature $62.62^{\circ} \mathrm{C}$ and ambient temperature $44.50^{\circ} \mathrm{C}$.

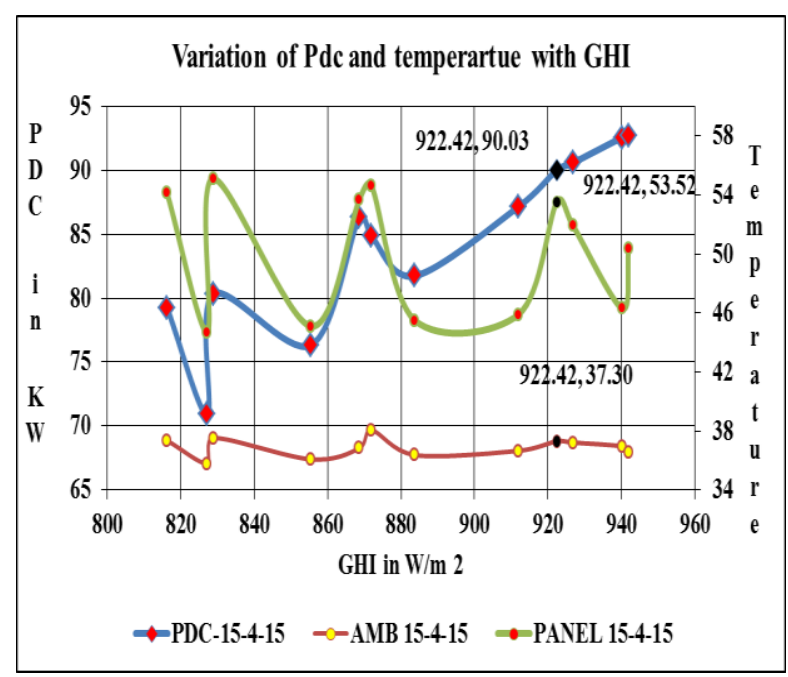

Fig 3: Variation of de power output for GHI $>800 \mathrm{~W} / \mathrm{m}^{2}$ for $15^{\text {th }}$ April 2015.

Figure 3 shows variation of $\mathrm{P}_{\mathrm{dc}}$ with GHI greater than 800 $\mathrm{W} / \mathrm{m}^{2}$. The ambient temperature varies between $35-38^{\circ} \mathrm{C}$ and panel temperature varies between $42-55^{\circ} \mathrm{C}$. Here $\mathrm{Pdc}$ increases with increase in ambient and cell temperature. The power output increases in direct proportion to irradiance. It increases from 70 to $92.58 \mathrm{KW}$ as $\mathrm{GHI}$ increases from 800 to $940 \mathrm{~W} / \mathrm{m}^{2}$. $\mathrm{P}_{\mathrm{dc}}$ equal to $90.03 \mathrm{KW}$ is obtained at ambient temperature $37.30^{\circ} \mathrm{C}$ and cell temperature $53.52^{\circ} \mathrm{C}$. This shows that $\mathrm{P}_{\mathrm{dc}}$ has positive temperature coefficient for ambient temperature up to $35-38^{\circ} \mathrm{C}$ and cell temperature up to $50-54^{\circ} \mathrm{C}$.

It is seen that in winters specifically $15^{\text {th }}$ December (Figure 4) maximum temperature is around $25^{\circ} \mathrm{C}$, maximum $\mathrm{GHI}$ is around $700 \mathrm{~W} / \mathrm{m}^{2}$ and the $\mathrm{PV}$ module does not give the desired power output.

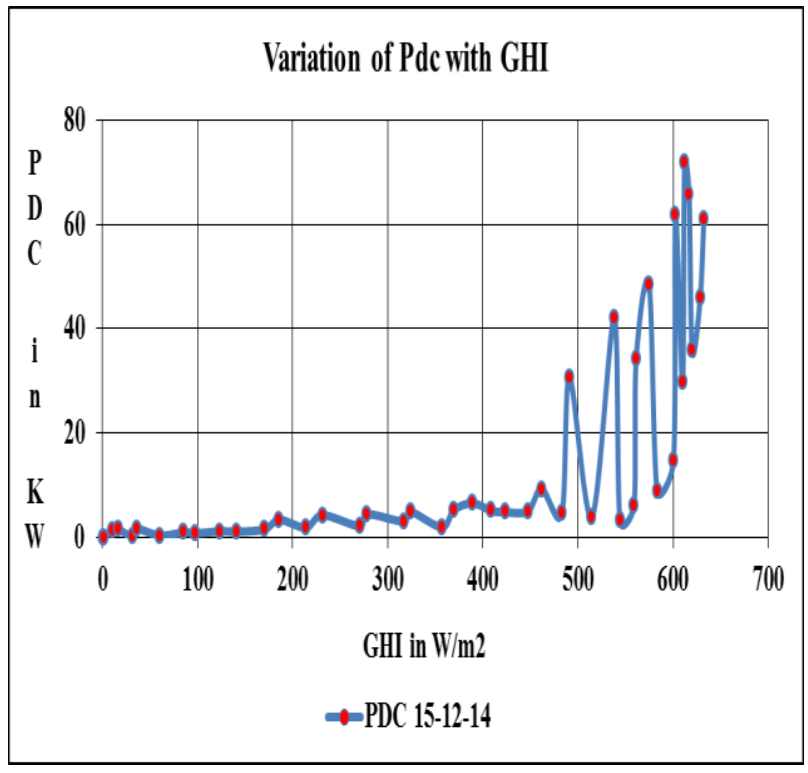

Fig 4: Variation of dc power output with GHI for $15^{\text {th }}$ December 2014

The output goes high for very short duration indicated by very few points in figure 4 while in summer much higher output is obtained for enormous points (figure1) that is for longer span. High temperature and high irradiance for long duration will give higher dc output for longer duration and corresponding power yield will also be higher.

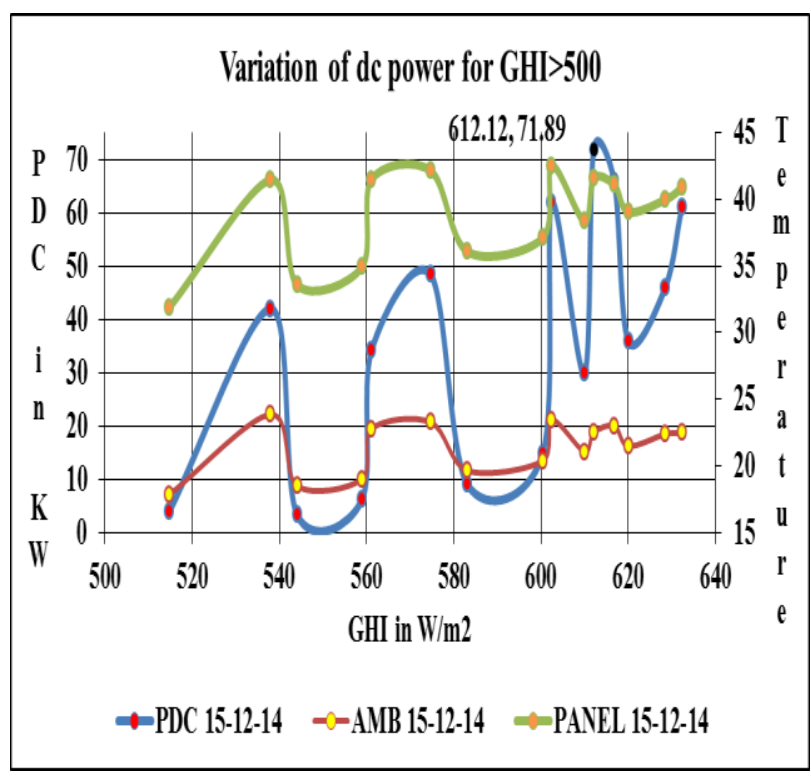

Fig 5: Variation of dc power output with GHI greater than $500 \mathrm{~W} / \mathrm{m}^{2}$ for $15^{\text {th }}$ December 2014.

The detailed view of figure 4 is shown in figure 5 . It can be seen that $\mathrm{P}_{\mathrm{dc}}$ increases as ambient and panel temperature increases as ambient temperature is less than $35^{\circ} \mathrm{C}$ and panel temperature is less than $50^{\circ} \mathrm{C}$. Maximum $\mathrm{P}_{\mathrm{dc}}$ is $71.89 \mathrm{KW}$ at ambient temperature $22.51 \mathrm{C}$ and cell temperature $41.55 \mathrm{C}$. 


\section{RESULT AND DISCUSSIONS}

(i) The multicrystalline PV module works more efficiently at cell temperature around $50-55^{\circ} \mathrm{C}$. Positive temperature coefficient is observed as long as cell temperature is less than $53^{\circ} \mathrm{C}$ as shown in figure 3 .

(ii) Negative temperature for $\mathrm{P}_{\mathrm{dc}}$ is observed when cell temperature is greater than $50-55^{\circ} \mathrm{C}$ and ambient temperature is greater than $36-38^{\circ} \mathrm{C}$. However $\mathrm{P}_{\mathrm{dc}}$ increases in direct proportion to irradiance outweighing change in temperature.

(iii) Maximum $\mathrm{P}_{\mathrm{dc}}$ for specific day at $40^{\circ} \mathrm{C}, 53^{\circ} \mathrm{C}$ and $62^{\circ} \mathrm{C}$ cell temperature is $71 \mathrm{KW}, 90 \mathrm{KW}$ and 87.6 $\mathrm{KW}$ respectively. Noteworthy output is not attained until cell temperature is greater than $35^{\circ} \mathrm{C}$ and $\mathrm{GHI}$ is greater than $600 \mathrm{~W} / \mathrm{m}^{2}$.

(iv) Long duration of high irradiance in summer (figure 1) gives much higher output compared to shorter span in winter as in December (figure 4) .

(v) The module efficiency varies in direct proportion to dc output power. Therefore multicrystalline module works very efficiently in critically high temperature of Western Rajasthan.

(vi) Negative temperature coefficient for maximum dc power (Pmax), needs to be revaluated for the real time conditions.

(vii) Western Rajasthan is highly suitable for solar photovoltaic power generation.

(viii) Low cost concentration technique to capture maximum solar irradiance should be employed in order to increase dc power output especially in winters in Western Rajasthan and year round in the countries receiving low solar irradiance. If successful it can reduce the cost significantly and can give new impetus to solar industry.

\section{CONCLUSION}

The analysis of real time data in critical climatic conditions of Western Rajasthan show that multicrystalline PV module works very efficiently even at extremely high temperature. $\mathrm{P}_{\mathrm{dc}}$ in the range of $70-93 \mathrm{KW}$ is attained as ambient temperature varies from $35-38^{\circ} \mathrm{C}$ and cell temperature varies from 42 $55^{\circ} \mathrm{C}$. Maximum output is attained for cell temperature in the range of $50-55^{\circ} \mathrm{C}$. Negative temperature coefficient for $\mathrm{P}_{\mathrm{dc}}$ is seen for cell temperature greater than $52^{\circ} \mathrm{C} . \mathrm{P}_{\mathrm{dc}}$ increases with increase in irradiance outweighing change in temperature. If somehow cell temperature is maintained near $50^{\circ} \mathrm{C}$ with increase in GHI above $800 \mathrm{~W} / \mathrm{m}^{2}$, the module efficiency will improve. Efforts must be made to capture maximum irradiance. The findings are very important for Western Rajasthan and other countries experiencing record high temperature and high insolation. As a further work impact of employing concentration technique to increase solar insolation on the dc power output should be studied. Temperature coefficient for dc power needs to be re-evaluated for the real time weather conditions.

\section{ACKNOWLEDGMENT}

The authors would like to acknowledge the support of Shri J. K. Borgohain, Executive Director, Rajasthan Project. Oil India Lmt., Jodhpur, Shri D. C. Gogoi, Head, Technical
Service, Oil India Lmt, Jodhpur; Shri Rajesh Kundoo, Incharge, PV Power Plant at Ramgarh, Jaisalmer in conducting this study.

\section{REFERENCES}

[1] Masters, G. M. 2004. Renewable and efficient electric power systems. Wiley Interscience.

[2] Garg, S. JB, Arun. 2016. High Temperature Effect on Multicrystalline Photovoltaic Module in Western Rajasthan, India. Journal of Communications on Applied Electronics (CAE), Foundation of Computer Science FCS, New York, USA, January 2016, Vol. 4, No.2, 4448.

[3] http://www.gits4u.com/renew/renew5.htm

[4] Makhija, B. K. 2012. Solar power in Rajasthan, Challenges and Issues in Solar RPO Compliance/ RECs. 24 July 2012, New Delhi.

[5] Green, M A., Emery, K., Hishikawa, Y., Warta, W. and Dunlop, E. D. 2014. Solar cell efficiency tables (version 44), journal of Progress in Photovoltaics research and applications, John Wiley \& Sons, Ltd, July 2014; Vol. 22, Issue 7, 701-710.

[6] Muzathik, A. M. 2014. Photovoltaic Modules Operating Temperature Estimation Using a Simple Correlation, International Journal of Energy Engineering, Aug. 2014, Vol. 4, No. 4, 151-158.

[7] Kozak, T., Maranda, W., Napieralski, A., Mey, G. D. and Vos, A. D. 2009. Influence of Ambient Temperature on the Amount of Electric Energy Produced by Solar Modules. 16th International Conference on Mixed Design of Integrated Circuits and Systems, Poland.

[8] Chaturvedi, D. K. and Sharma, S. 2015. An experimental study and verification of the facts related to factors affecting the performance of solar PV systems. Fifth International Conference on Communication Systems and Network Technologies.

[9] Touati, F., Massoud, A., Hamad, J. A. and Saeed, S. A. 2013. Effects of Environmental and Climatic Conditions on PV Efficiency in Qatar. International Conference on Renewable Energies and Power Quality, Bilbao (Spain), $20^{\text {th }}$ to $22^{\text {th }}$ March, Renewable Energy and Power Quality Journal, Vol. 11.

[10] Magal, B. S. 1994. Solar Power Engineering, Tata McGraw-Hill Publishing Company Limited.

[11] Javaid, M. A., Hassan, M. H., Khan, M. S. and Shaukat, S. F. 2011. Estimation of Solar Power Efficiency in Day Time at Different Temperatures. International Journal of Electrical \& Computer Sciences, Vol. 11, No. 02, 48-52.

[12] Gupta, A., Khare, A. and Shrivastava. A. 2014. Modelling of Solar Photovoltaic Module and Effect of Variation of Insolation Using Matlab / Simulink. International Journal of Electrical, and Computer Engineering, Vol. 3, No. 1, 126-131.

[13] Sen, Zekai. 2008. Solar energy fundamentals and modeling techniques: atmosphere, environment, climate change and renewable energy. Springer 
[14] Didier, T. and Richmond, B. C. 2005. Review and recommendations for improving the modelling of building integrated photovoltaic systems. Ninth International IBPSA Conference Montréal, Canada.

[15] Elminir, K. H., Benda, V. and Tousek, J. 2001. Effects of solar irradiation conditions and other factors on the outdoor performance of photovoltaic modules. Journal of electrical engineering, Vol. 52, No. 5-6, 125-133.

[16] http://rredc.nrel.gov/solar/glossary/gloss_g.html

[17] Buday, S. M. 2011. Measuring irradiance, temperature and angle of incidence effects on photovoltaic modules in Auburn Hills, Michigan. A practicum submitted in partial fulfilment of the requirements for the degree of Master of Science/Sustainable Systems (Natural Resources and Environment) at the University of Michigan. Advisors- Professor Keoleian, G. Marion, C.B. Principal Scientist and Project Leader of Photovoltaic Research NREL.

[18] Taleb, H. Al-theanat and Lpizra, A. Mhd. 2015. The Effects of Intermittent Solar Radiation in Off-grid Solar Power System a Case Study of Two Cities; Irbid and Abu Dhabi 'Worst Month' Method. International Journal of Engineering Innovation \& Research Vol. 4, Issue 4, 2015, 544-549.

[19] El-Shaer, A., Tadros, M. T. Y. and Khalifa, M. A. 2014. Effect of Light intensity and Temperature on Crystalline Silicon Solar Modules Parameters. International Journal of Emerging Technology and Advanced Engineering, Vol. 4, Issue 8, August 2014, 311-318.

[20] Ike, C. U. 2013. The Effect of Temperature on the Performance of a Photovoltaic Solar System in Eastern Nigeria. Research Inventory, International Journal of Engineering and Science, Vol.3, Issue 12, December 2013, 10-14.

[21] Patsalides, M., Evagorou, D., Makrides, G., Achillides, Z., Georghiou, E. G., Stavrou, A., Efthimiou, V., Zinsser, B., Schmitt, W. and Werner, H. J. 2007. The Effect of Solar Irradiance on the Power Quality Behaviour of Grid Connected Photovoltaic Systems. International Conference on Renewable Energies and Power Quality (ICREPQ'07)", Sevilla 28-30 Mach 2007.

[22] Singla, V. and Garg, V. K. 2013. Modeling of solar photovoltaic module \&effect of insolation variation using Matlab/Simulink, International Journal of Advanced Engineering Technology, Vol. IV, No. III, July-Sept., 2013, 05-09.

[23] Dash, P. K. and Gupta, N. C. 2015. Effect of Temperature on Power Output from Different
Commercially available Photovoltaic Modules". Int. Journal of Engineering Research and Applications www.ijera.com, ISSN: 2248-9622, Vol. 5, Issue 1, Part $1,148-151$.

[24] Kumar, B. S. and Sudhakar, K. 2015. Performance evaluation of $10 \mathrm{MW}$ grid connected solar photovoltaic power plant in India, Energy Reports 1, 2015, 184-192

[25] Albuquerque, F. L., Moracs, A. J., Guimaracs, G. C., Sanhueza, S. M. R. A. R. and Vaz, A. R. 2004. Optimization of a Photovoltaic System Connected to Electric Power Grid IEEE/PES Transmission \& Distribution Conference \& Exposition, Latin America, November 2004, 645-650.

[26] Mayfield, R. 2010. Photovoltaic design and installation for dummies. Wiley Publishing Inc.

[27] Dubey, S., Sarvaiya, J. N. and Seshadri, B. 2012. Temperature Dependent Photovoltaic (PV) Efficiency and Its Effect on PV Production in the World A Review. PV Asia Pacific Conference 2012, Energy Procedia, Vol. 33, 311-321.

[28] Vasisht, M. S., Srinivasan, J. and Ramasesha, S. K. 2016 Performance of solar photovoltaic installations: Effect of seasonal variations, Solar Energy 131, 39-46

[29] California Energy Commission. A Guide to Photovoltaic (PV) System Design and Installation report, page 8, section 2.3.1 Factors Affecting Output, Standard Test Conditions. www.energy.ca.gov/reports/2001-09-04_500 -01- 020.PDF.

[30] Bradford, T. 2006. Solar Revolution: The Economic Transformation of Global Energy Industry. MA.

[31] Dallakyan, V. and Vardanyan, V. 2007. Mirror reflecting cost effective PV solar energy, concentrating system. Proceedings of the $4^{\text {th }}$ International Conference on Solar Concentrators for the Generation of Electricity or Hydrogen (ICSC-4), 12-16 March 2007, San Lorenzo del Escorial, Spain, 141-143.

[32] Pradhan, A., Ali, S. M. and Jena, C. 2013. Analysis of Solar PV cell Performance with Changing Irradiance and Temperature. International Journal of Engineering and Computer Science, Vol. 2, No. 1, 214-220.

[33] Muller, B., Hardt, L., Armbruster, A., Kiefer, K. and Reise, C. 2014. Yield Predictions for photovoltaic power plants: Empirical, Validation, Recent Advances and remaining uncertainites, Presented at $29^{\text {th }}$ European PV Solar Energy Conference and Exhibition, 22-26 September 2014, The Netherlands. 